\title{
Application of e-business in general elections (Study of utilization of a single identity number to support in the election process)
}

\author{
Yudo Devianto* \\ Faculty of Computer Science, Universitas Mercu Buana, Jakarta, Indonesia
}

Received: 19-May-2020; Revised: 21-July-2020; Accepted: 24-July-2020

(C)2020 Yudo Devianto. This is an open access article distributed under the Creative Commons Attribution (CC BY) License, which permits unrestricted use, distribution, and reproduction in any medium, provided the original work is properly cited.

\begin{abstract}
In approaching the technology era 4.0, providing the best service to the community is something that must be provided by the government, of course, the service must be supported by reliable and up-to-date information technology. One of the problems faced is how to provide the best results in providing services to the community. The services referred to in this study relate to a series of general election activities, where most people do not get the best service, including those not registered in permanent voters, some are not able to exercise their voting rights because their position is not close to the election location where they are registered. This research also expects the support of related parties so that this research can produce solutions that can be used to solve existing problems. Referring to the background of this study, the problems that can be identified are as follows: 1. Many people who can't be registered as permanent voters, 2. Can't exercise their right to vote, because the position at the election is not close to the location where they are registered as voters, 3 The number of ballots is damaged, or invalid so that voters can't use their voting rights. The scope of the problem is research focused on providing solutions so that the problem can be solved by utilizing information technology. The concept of $E$ Business will be applied in this research, namely Business to Government (B2G). The research method we use is applied research, because the results of the research can be directly used to solve problems faced and the application of $E$ Business by using the information systems development (ISD) method. The results achieved are applying the concept of Business to Government (B2G), which can be seen in Business to Government (B2G) business processes.
\end{abstract}

\section{Keywords}

The best service, Permanent voters, Elections, Voting rights, Damaged ballots, E-business, B2G, Business to government.

\section{Introduction}

In approaching the technology era 4.0, providing the best service to the community is something that must be provided by the government, of course, the service must be supported by reliable and up-to-date information technology. One of the problems faced is how to provide the best results in providing services to the community [1-3]. The services referred to in this study relate to a series of general election activities, where most people do not get the best service, including those not registered in permanent voters, some are not able to exercise their voting rights because their position is not close to the election location where they are registered [4]. The purpose of this study is to provide a solution to the problems encountered by using or the concept of EBusiness [5].

\footnotetext{
*Author for correspondence
}

This research also expects the support of related parties so that this research can produce solutions that can be used to solve existing problems and where later this research can also contribute to the nation by applying the concept of E-Business in it.

\subsection{Research problems}

1.1.1Identification of problems

Referring to the background of this research, the problems that can be identified are: 1. Many people who can't be registered as permanent voters, 2. Can't exercise their right to vote, because the position at the election is not close to the location where they are registered as voters.

1.1.2Research restrictions

The scope of the problem is research focused on providing solutions so that the problem can be solved by utilizing information technology.

1.1.3Research purposes

Based on the identification of problems, the aim of the research is to create something that can solve existing problems by utilizing information 
technology, which is in the form of applying the concept of E-Business [6,7].

\subsection{Research objectives and benefits}

1.2.1Research purposes

Referring to the identification of problems, the purpose of research is to make something that can solve existing problems by applying the concept of E-Business.

1.2.2Benefits of research

The benefits of the resulting research are expected: 1 . Can be used as a medium for data collection of general election participants or regional head elections, 2. Can be used by government agencies for data collection of general election participants or regional head elections.

\section{Research method}

\subsection{Research methods}

The research method we use is applied research, because the results of the research can be directly used to solve problems faced and the application of E-Business by using the information systems development (ISD) method [8].

Traditional systems development life cycle (SDLC) methods provide structured and formal steps. But the
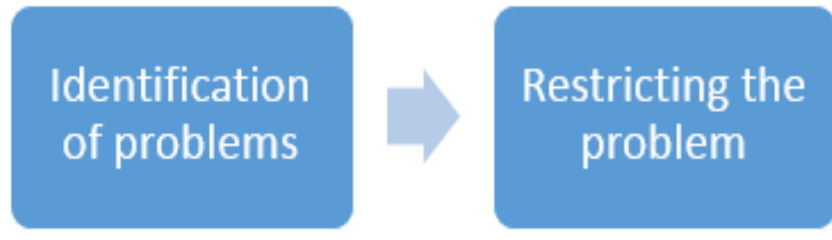

Figure 1 Diagram of research stages

\section{a. Identification of problems}

Referring to the background of this research, the problems that can be identified are:

1. Many people who can't be registered as permanent voters.

2. Can't exercise their right to vote, because the position at the election is not close to the location where they are registered as voters.

\section{b. Restricting the problem}

The scope of the problem is focused on providing solutions so that the problem can be solved by implementing E-Business.

\section{c. Formulation of the problem}

The main problem that will be examined in this research is how to produce the best solution that can method needs to be changed to adjust to the conditions of information technology and needs that are increasingly complex and require flexibility and great responsiveness.

For the development of e-business in this cluster, a combination of SDLC advantages that are structured and formal.

1.In this research, it will be shown the application of E-Business in solving existing problems.

2.The results of research in the form of scientific journals and the concept of applying e-business.

\subsection{Data collection methods}

Data collection methods used in this study are: 1 . Observation or direct observation of research objects, observation techniques are carried out by structured observation by preparing a list of data requirements and data sources, 2. Literature study, data collection methods obtained by researching, studying, reading books, and looking for information from the internet in the form of journals related to E-Business and elections [9].

Figure 1 Shows the diagram of research stages.

\subsection{Research stages}

\section{Formulation of the problem}

later be used to solve existing problems and hopefully this solution can be used for those who have the same problem.

\subsection{System planning}

The system design determines, how the system will be able to solve existing problems, several things that are in the design of the system include, designing hardware, software, network infrastructure. System design is an advanced stage of system analysis [10] where the system design illustrates the system to be built before coding in a programming language. In the design of a system can't be separated from the results of the analysis. The system design in this study is illustrated in the form of a concept, which can be seen in Figure 2. 


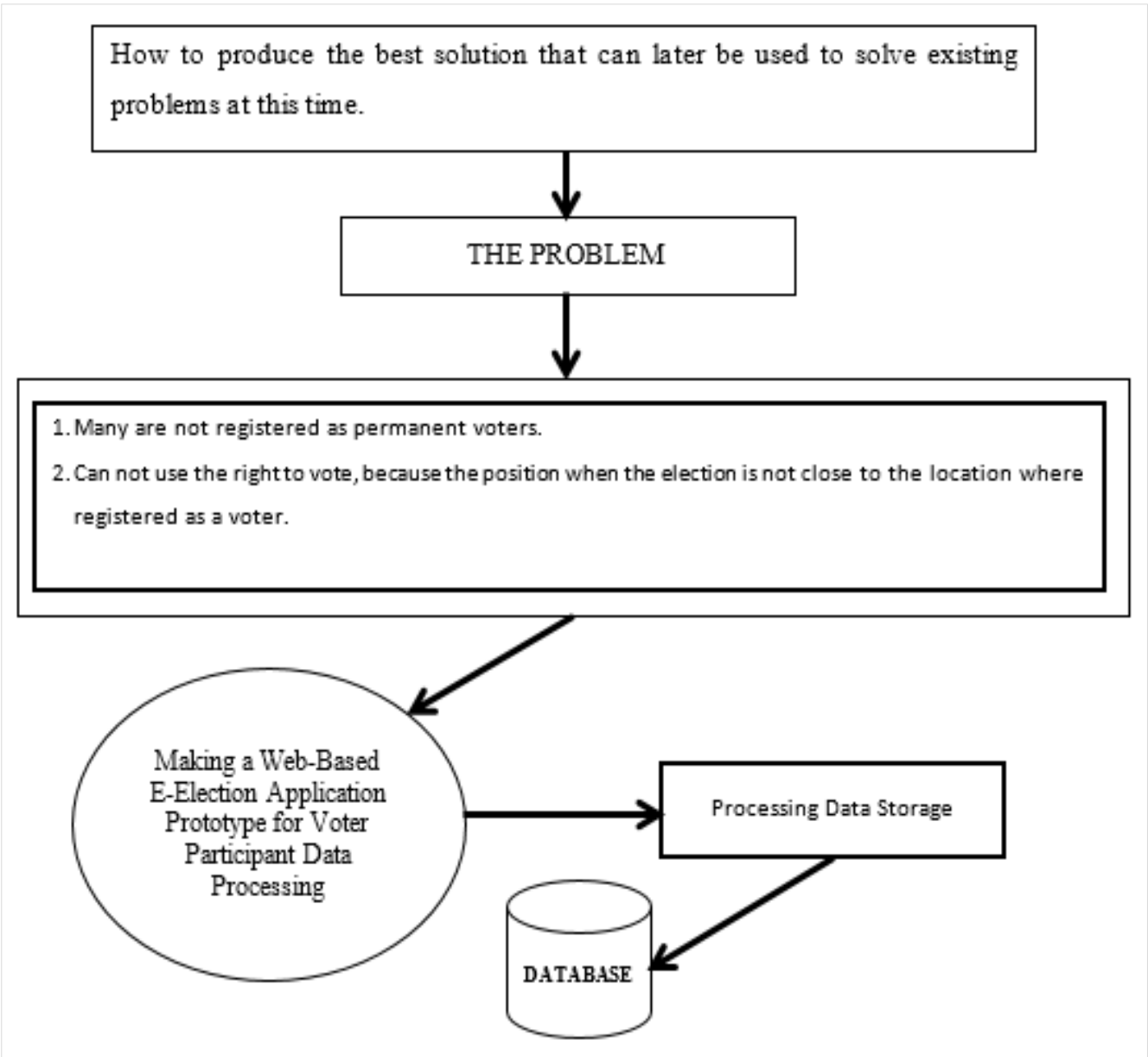

Figure 2 Research concept

Explanation for Figure 2 as follows:

1. How to produce the best solution that can later be used to solve existing problems at this time.

2. Identifying existing problems.

3. Generate a solution by creating an application program for processing the data on election participants.

4. The processed election participant data is stored in a database that has been prepared.

This research is expected to provide the best solution of the existing problems, the expected solution is to make a prototype of the E-Election application to be able to process the data of election participants.

\section{Results}

\subsection{Deployment diagram}

Deployment diagram [10] is a diagram that can provide an explanation of how some physical elements compile and run the system in a network that will be formed. Deployment describes the details of how components are deployed in the system infrastructure, where the components will be located on the machine, server or PC, and shows how the network capabilities at that location, server specifications, and other things that are physical and in this information system there are components that support the running of the E-Election Application:

1. Popojicms Web Framework, tools used to create E-Election Applications.

2. Local Host Xampp Web Server, used to connect databases with E-Election Applications.

3. The database and localhost are stored on the server

4. E-Election can be used to help the data collection of general election participants or regional heads.

Figure 3 shows the deployment of E-election application diagrams. 


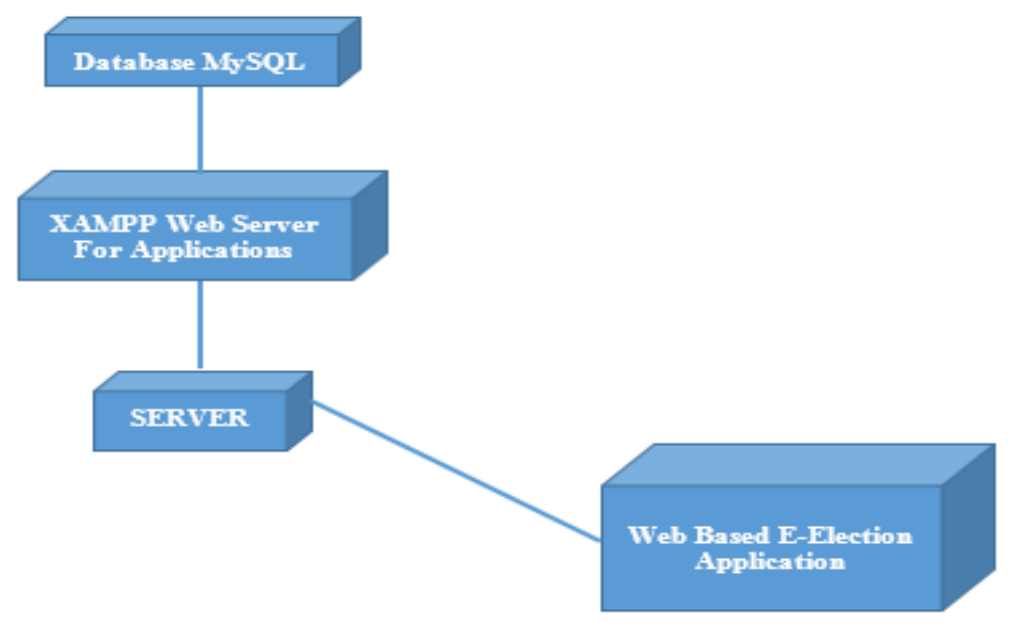

Figure 3 Deployment of E-election application diagrams

3.2Designing architectural infrastructure

At this stage the concept of applying E-Business to the E-Election application is used, which is used to process data on general election participants or regional head elections.

The research aid Table 1 used is:

Table 1 Research Aids

\begin{tabular}{ll}
\hline No & Information \\
\hline 1 & Laptop Core I3, Windows 7 \\
\hline
\end{tabular}

\section{DEVELOPMENT CONCEPT}

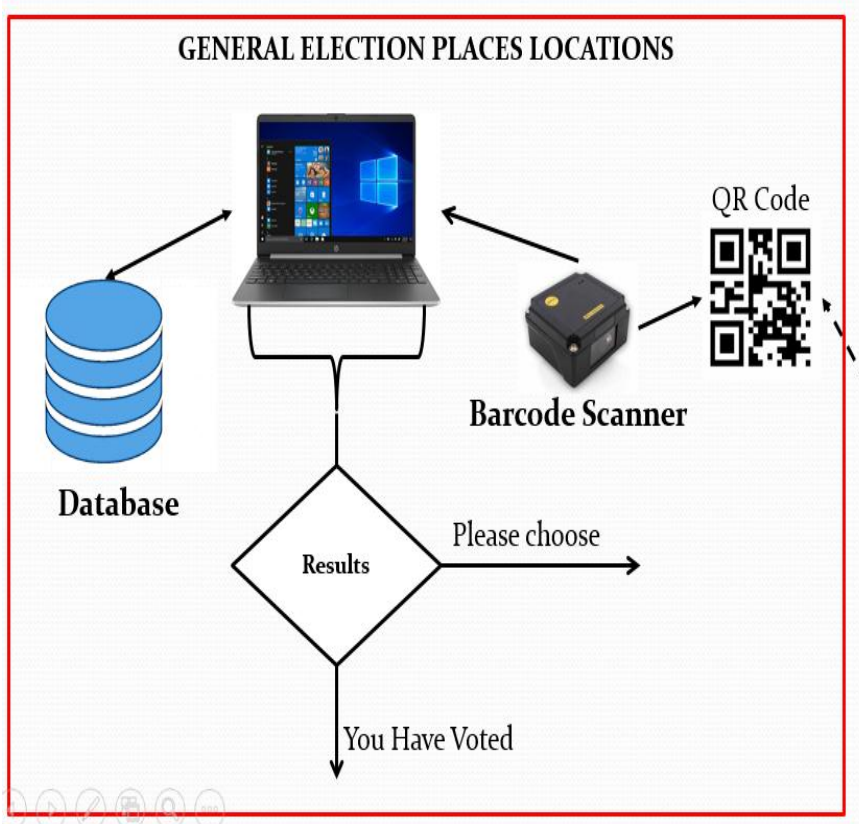

Figure 4 Application development concepts

\begin{tabular}{ll}
\hline No & Information \\
\hline 2 & Barcode Scanner Type \\
& EP2000 \\
\hline 3 & XAMPP Sebagai Server \\
& Localhost \\
\hline 4 & Popojicms Web Framework \\
\hline
\end{tabular}

The infrastructure design of the E-Election Application is as follows: 
In Figure 4, it looks at the infrastructure design model, which consists of:

\section{a. Location of online registration}

1. Prospective voters continue to register online on the web application that has been provided, by filling out the required identity.

2. After registering the data prospective voters will still be stored in the database.

3. Indicating that the online registration was successful, voters will get a QR Code, and later the QR Code [11] will be shown to the election location during the election. b. Location of election place

1. QR Code carried by voters, scanned to validate data.

2. The QR Code is read and the results appear that the data matches those who are dating, then potential voters may vote.

3. And if the QR Code results are not valid, then potential voters are not allowed to vote.

\subsection{Single identity application}

Flow Diagram of the use of the E-Election registration application is shown in Figure 5.

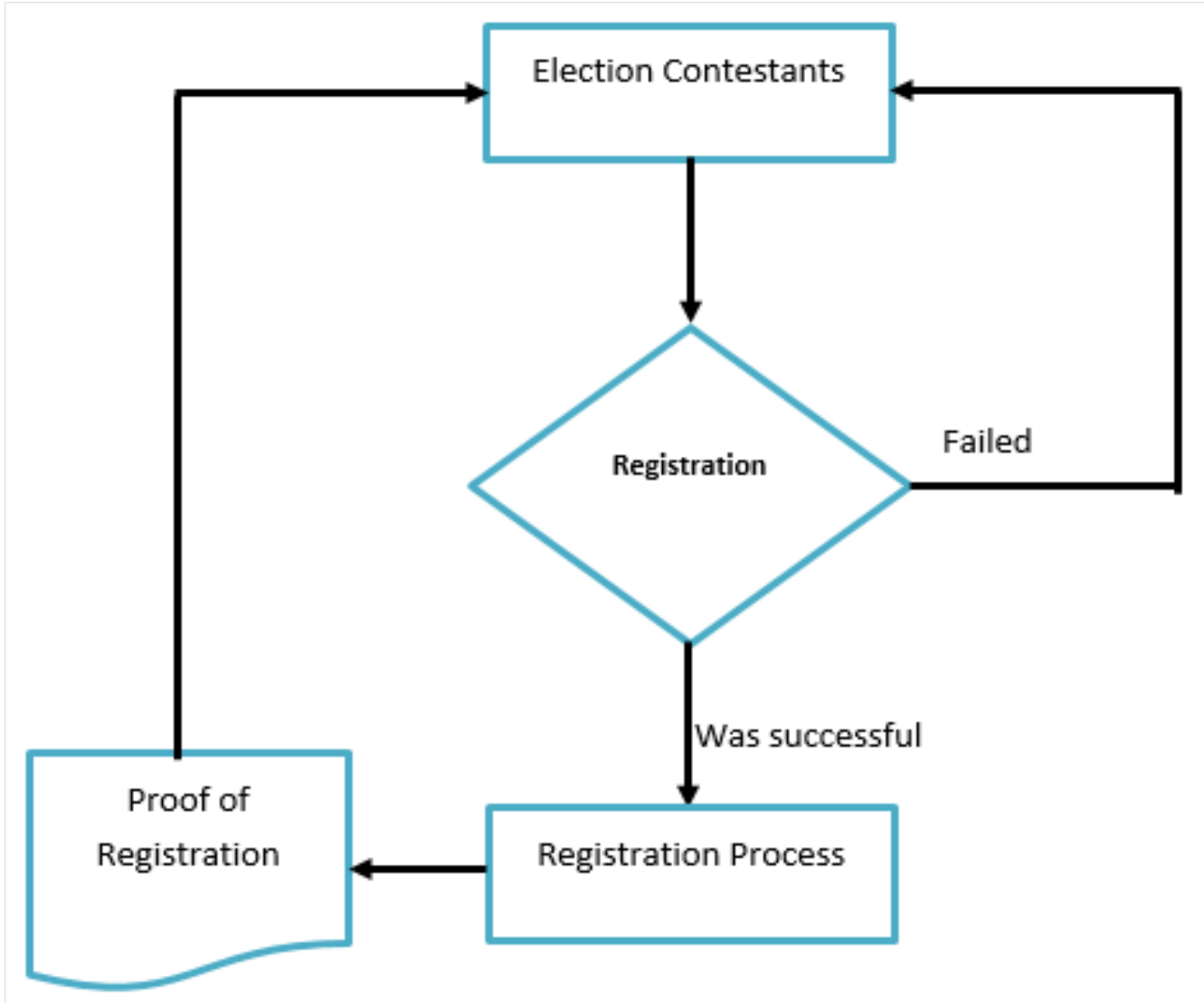

Figure 5 Flow Diagram of the use of the E-election registration application

1. Election participants carry out the registration using the E-Election registration application

2. If the registration fails, return to the election participants.

3. Registration was successful, proceed to the registration process and

4. Produce proof of registration held by the election participants.
5. Election participants enter a single identity number on the election participant registration web application.

6. Then the application raises data based on a single identity number that is in the population database owned by the government.

7. The data that appears is in accordance with the relevant data, then starts registering the data of election participants. 
8. Successfully registered, will receive proof of registration of election participants, which contains a QR Code [11] and photos of election participants.

9. Evidence of registration of participants in this election which will be brought to the location of the election as valid evidence of voters.

Proof of registration is used to use the right to vote at the location of the election, without carrying proof of registration, election participants are not allowed to vote.

Illustration diagram of a single identity data that will be used in the election data collection.

From Figure 6 we can see the process of using a single identity number that is used to register or update data on election participants:

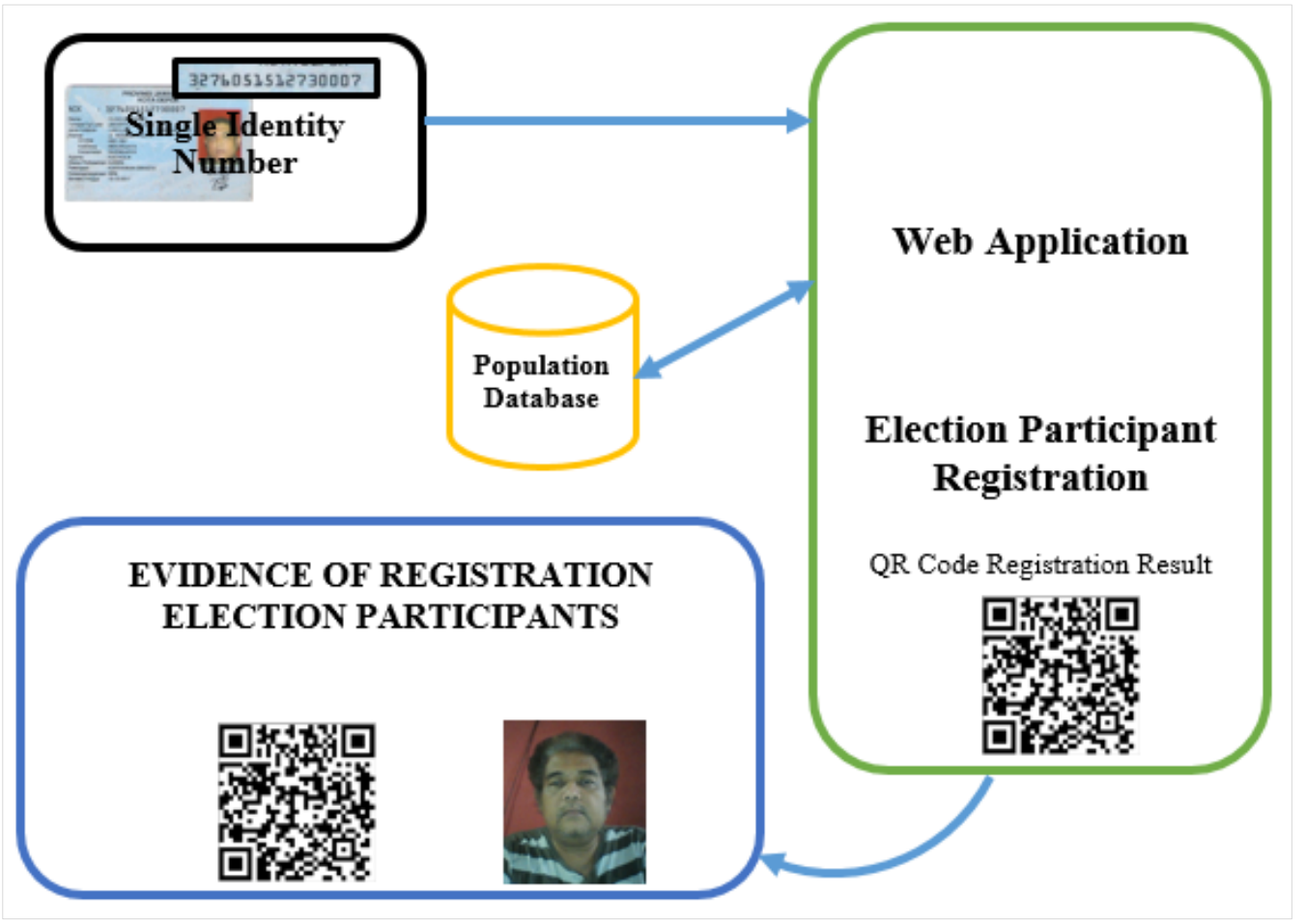

Figure 6 Illustration of the Use of a single identity

\section{Discussion}

4.1E-Business implementation

The implementation of E-Business that will be applied is Business to Government (B2G) $[12,13,6]$, where later the private sector as an application manufacturing service provider collaborates with the government to implement this E-Election application. The Business to Government E-Election Model can be seen in Figure 7.

In Figure 7, it can be explained as follows, businesses or service providers providing applications, providing or making E-Election applications that can be used by the government with a leasing system or opening tenders for making EElection applications. Which later the application can be used by prospective voters, it can be seen in
Figure 6, where the Single Identity Number can be used, and the ownership of the Single Identity Number data is only owned by the government.

The business process of the $\mathrm{B} 2 \mathrm{G}$ concept can be seen in the picture below:

From Figure 8, it can be seen that application service providers work together with the government to create E-Election applications which will be used by election participants to register and conduct elections. Therefore, the application of E-Business B2G is highly recommended for making an E-Election application, without collaboration with the government the E-Election application can't be used at the national or regional scale. 


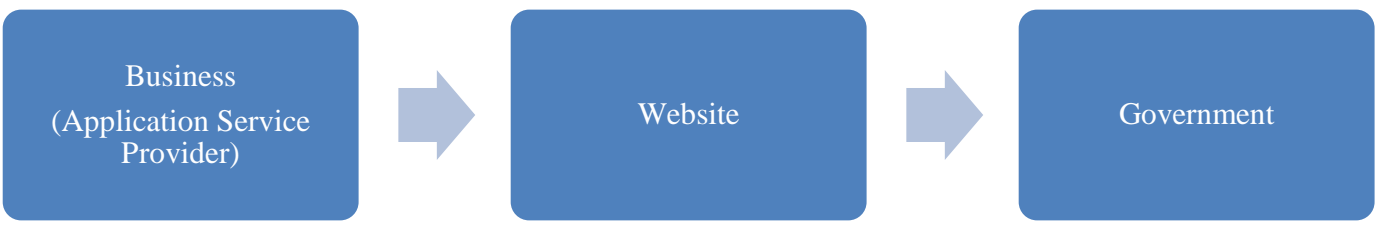

Figure 7 Business to Government E-election model

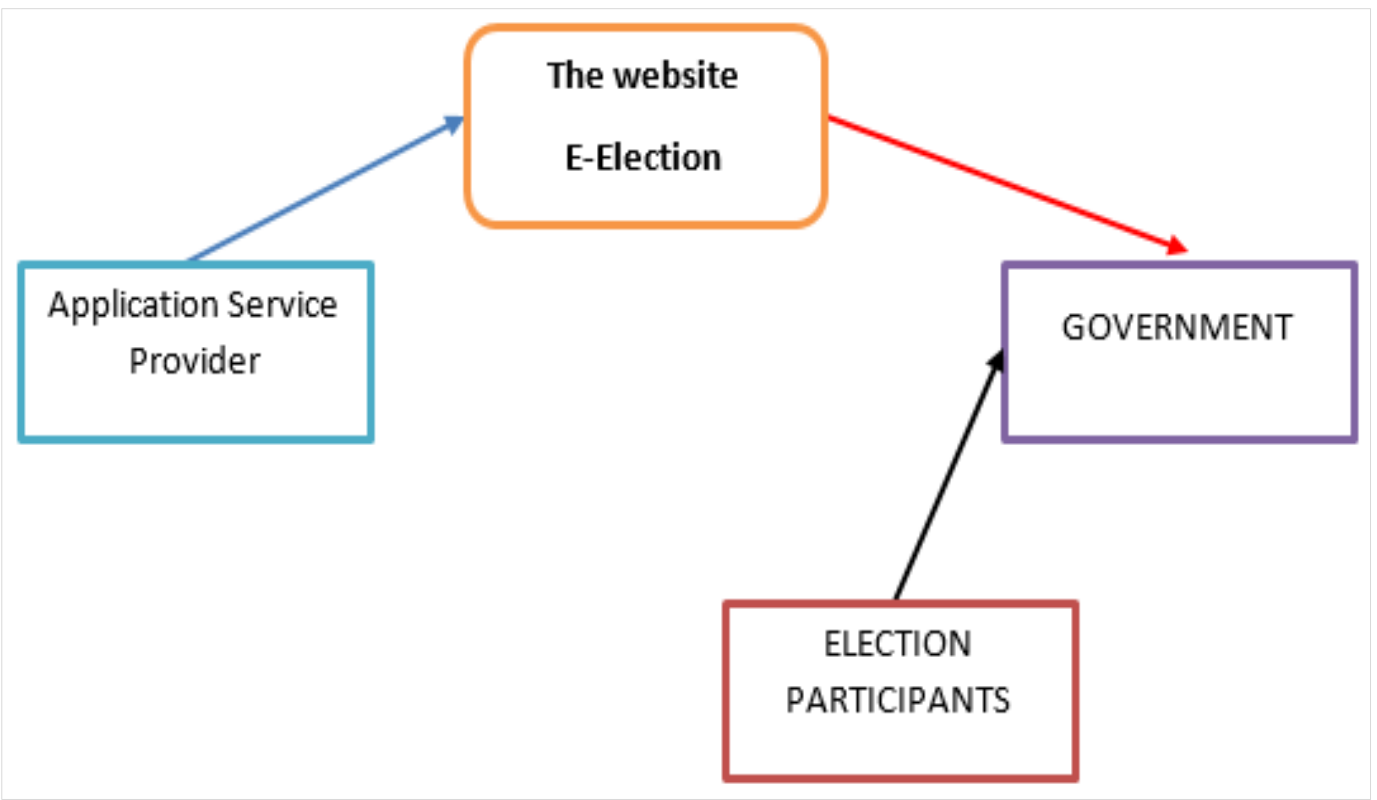

Figure 8 Business process of the B2G concept E-election

\section{Conclusion}

From the results of the discussion of the research that has been done, then in the study "Application of $E$ Business In General Election (Study of Utilization of a Single Identity Number to Support In the Election Process)" conclusions and suggestions can be drawn as follows:

1. E-Election applications can't be made without cooperation with the government.

2. By using the E-Election application, the public can easily register themselves as participants in the election or local elections.

3. The results of this study are the application of EBusiness (B2G) to support the creation of EElection Applications that can be used as solutions to problems that occur in the community.

4. Later the data generated is information data about the election participants or the regional head election.
5. Our suggestion is that this application can be made by inviting government cooperation as the owner of the Single Identity Number data.

\section{Acknowledgment}

Our gratitude goes to God for all His graces and gifts so that this research can be completed well. We thank the extended family of the Faculty of Computer Science, Universitas Mercu Buana, and especially the Universitas Mercu Buana Research Center for providing research funding support. The theme chosen in this internal research activity was "APPLICATION OF E-BUSINESS IN GENERAL ELECTIONS (Study of the Use of a Single Identity Number to Support the Selection Process)". The author realizes that this report is far from perfect and therefore constructive criticism and suggestions so that the authors hope to be better. Hopefully this report can provide benefits to readers. Thanks. SPK: 02-5 / 183 / B-SPK / III / 2020. 


\section{Conflicts of interest}

The authors have no conflicts of interest to declare.

\section{References}

[1] https://www.jogloabang.com/teknologi/pp-40-2019pelaksanaan-uu-232006-administrasi-kependudukan. Accessed 20 April 2020.

[2] Nurhasim M. Paradoks pemilu serentak 2019: memperkokoh multipartai ekstrem di Indonesia. Jurnal Penelitian Politik. 2020; 16(2):125-36.

[3] Fahmi K, Amsari F, Azheri B, Kabullah MI. Sistem keadilan pemilu dalam penanganan pelanggaran dan sengketa proses pemilu serentak 2019 di sumatera barat electoral justice system in handling. Jurnal Konstitusi.2020.

[4] Zuhro RS. Demokrasi dan pemilu Presiden 2019. Jurnal Penelitian Politik. 2019; 16(1):69-81.

[5] Kollmann T. E-business. Springer Fachmedien Wiesbaden; 2019.

[6] Fahmi I, Fachruddin R, Silvia V. Analisis E-business pada keputusan kewirausahaan bisnis digital (Sebuah Kajian Literatur Studi). In prosiding seminar nasional kewirausahaan 2019 (pp. 71-5).

[7] Saura JR, Palos-Sanchez PR, Correia MB. Digital marketing strategies based on the e-business model: literature review and future directions. In Organizational Transformation and Managing Innovation in the Fourth Industrial Revolution 2019 (pp. 86-103). IGI Global.

[8] Gunawan W. Pengembangan aplikasi berbasis android untuk pengenalan huruf hijaiyah. Jurnal Informatika. 2019; 6(1):69-76.
[9] Masduki A, Widyatama R. Efektifitas strategi komunikasi politik elit muhammadiyah DIY dalam Pemenangan Pemilu DPD-RI Tahun 2014. Communicare: Journal of Communication Studies. 2019; 5(1):1-18.

[10] Perez-Palacin D, Merseguer J, Requeno JI, Guerriero M, Di Nitto E, Tamburri DA. A UML profile for the design, quality assessment and deployment of dataintensive applications. Software and Systems Modeling. 2019; 18(6):3577-614.

[11] Xu M, Su H, Li Y, Li X, Liao J, Niu J, et al. Stylized aesthetic QR code. IEEE Transactions on Multimedia. 2019; 21(8):1960-70.

[12] Damayanti F, Alkindira S. Pengelolaan digital filing sebagai bentuk penerapan E-business di PT dirgantara Indonesia. Jurnal Sekretaris \& Administrasi Bisnis. 2019; 3(2):180-9.

[13] Rohman F. Implementasi tqm dan strategi e bisnis dalam optimalisasi penjualan E toll card. SNIT 2012. 2019; 1(1):1-7.

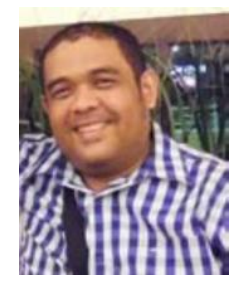

Yudo Devianto, received the Bachelor degree in Computer Science from Universitas Budi Luhur, Jakarta, Indonesia in 2002 and the Master degree in Computer Science from Universitas Budi Luhur, Jakarta, Indonesia in 2015. From 2015 - Now, he is an Assistant Professor from Universitas Mercu Buana, in Faculty of Computer Science, major Information System. He is also a researcher at Universitas Mercu Buana, in the field of research, EBusiness, Knowledge Management, Machine Learning, Data Mining.

Email: yudo.devianto@mercubuana.ac.id 